\title{
Influence of metals and metalloids on the composition and fluorescence quenching of the extracellular polymeric substances produced by the polymorphic fungus Aureobasidium pullulans
}

\author{
Wenjuan Song $^{1,2} \cdot$ Yuyi Yang ${ }^{2,3} \cdot$ Xinjin Liang $^{2,4} \cdot$ Feixue Liu $^{2} \cdot$ Geoffrey Michael Gadd $^{2,5}$ (D)
}

Received: 3 February 2020 / Revised: 29 May 2020 / Accepted: 7 June 2020 / Published online: 23 June 2020

(C) The Author(s) 2020

\begin{abstract}
Aureobasidium pullulans is a ubiquitous and widely distributed fungus in the environment, and exhibits substantial tolerance against toxic metals. However, the interactions between metals and metalloids with the copious extracellular polymeric substances (EPS) produced by A. pullulans and possible relationships to tolerance are not well understood. In this study, it was found that mercury $(\mathrm{Hg})$ and selenium $(\mathrm{Se})$, as selenite, not only significantly inhibited growth of A. pullulans but also affected the composition of produced EPS. Lead $(\mathrm{Pb})$ showed little influence on EPS yield or composition. The interactions of EPS from A. pullulans with the tested metals and metalloids depended on the specific element and their concentration. Fluorescence intensity measurements of the EPS showed that the presence of metal(loid)s stimulated the production of extracellular tryptophan-like and aromatic protein-like substances. Examination of fluorescence quenching and calculation of binding constants revealed that the fluorescence quenching process for $\mathrm{Hg}$; arsenic (As), as arsenite; and Pb to EPS were mainly governed by static quenching which resulted in the formation of a stable non-fluorescent complexes between the EPS and metal(loid)s. Se showed no significant interaction with the EPS according to fluorescence quenching. These results provide further understanding of the interactions between metals and metalloids and EPS produced by fungi and their contribution to metal(loid) tolerance.
\end{abstract}

\section{Key points}

- Metal(loid)s enhanced production of tryptophan-and aromatic protein-like substances.

- Non-fluorescent complexes formed between the EPS and tested metal(loid)s.

- EPS complexation and binding of metal(loid)s was dependent on the tested element.

- Metal(loid)-induced changes in EPS composition contributed to metal(loid) tolerance.

Keywords Mercury $\cdot$ Selenium · Aureobasidium pullulans $\cdot$ Excitation-emission matrix (EEM) fluorescence spectra · Extracellular polymeric substances (EPS)

Geoffrey Michael Gadd

g.m.gadd@dundee.ac.uk

1 State Key Laboratory of Desert and Oasis Ecology, Xinjiang Institute of Ecology and Geography, Chinese Academy of Sciences, Urumqi 830011, China

2 Geomicrobiology Group, School of Life Sciences, University of Dundee, Dundee, Scotland DD1 5EH, UK
3 Key Laboratory of Aquatic Botany and Watershed Ecology, Wuhan Botanical Garden, Chinese Academy of Sciences, Wuhan 430074, China

4 Present address: Sustainable Environment Research Centre, Upper Glyntaff, University of South Wales, Pontypridd, Wales CF37 4BD, UK

5 State Key Laboratory of Heavy Oil Processing, Beijing Key Laboratory of Oil and Gas Pollution Control, College of Chemical Engineering and Environment, China University of Petroleum, Beijing 102249, China 


\section{Introduction}

Toxic metal and metalloid pollution of soil and water can cause serious ecological and environmental problems. Microbial bioremediation has long been regarded as an environment-friendly way to treat such pollution. Microorganisms including bacteria, yeasts, filamentous fungi, and algae have been widely investigated for the removal and treatment of toxic metals (De Philippis et al. 2011; Fomina and Gadd 2014; Gadd 2010; Yin et al. 2019). The interactions between microorganisms and metals can involve several processes, e.g., adsorption, bioprecipitation, redox transformations, ion exchange, and complexation by excreted metabolites and extracellular polymeric substances (EPS) (Gadd 2000, 2004; Gupta and Diwan 2017; Sheng et al. 2013). The EPS secreted by microorganisms have been proven to be a rich matrix of polymers, including polysaccharides, proteins, glycoproteins, nucleic acids, phospholipids, and humic acids, which are thought to promote cell-cell recognition/ communication and protect cells from adverse environmental conditions such as desiccation (Prabhakaran et al. 2016; Ravella et al. 2010; Zhang et al. 2015). Furthermore, EPS is believed to play an important role in the tolerance of microorganisms exposed to toxic metals acting as a protective barrier and also a matrix for geochemical transformations and bioprecipitation (Fomina et al. 2005; Hou et al. 2013; Naik et al. 2012). This has been observed in a variety of microorganisms, such as sulfate-reducing bacteria (Yue et al. 2015), iron-oxidizing bacteria (Liu et al. 2017), and the fungi Phanerochaete chrysosporium (Cao et al. 2018) and Beauveria caledonica (Fomina et al. 2005).

Aureobasidium pullulans de Bary (Arnaud) is a polymorphic fungus and can exist as yeast-like cells, hyphae, intermediate cellular and filamentous forms, and melanized chlamydospores (Gadd and Griffiths 1980; Gadd 1980, 1984). It is ubiquitous and widely distributed in the environment, and can be isolated from soil and water, and is an early-colonizing saprophyte on decaying leaves and various surfaces such as concrete, wood, leaves, and tree bark (Bhadra et al. 2008; Prasongsuk et al. 2018). A. pullulans shows substantial tolerance against toxic metals, e.g., lead, copper, nickel, and cadmium (Deshpande et al. 1992; Gadd and Mowll 1985; Mowll and Gadd 1984; Nakkeeran et al. 2018). The ability of A. pullulans to form melanized chlamydospores and hyphal structures can play a significant role in protection, acting as an efficient barrier for metals, preventing intracellular uptake, and able to accumulate large amounts of metals by biosorption (Gadd 1984; Gadd et al. 1984; Mowll and Gadd 1984). In the environment, A. pullulans can become the dominant organism on phylloplanes contaminated by aerially deposited lead and other metals (Bewley and Campbell 1980; Mowll and Gadd 1985). A. pullulans strains showed significant $\mathrm{Pb}$ tolerance when grown on solid media containing $7.5 \mathrm{mM} \mathrm{Pb}^{2+}($ Rhee et al. 2014) and able to remove $\mathrm{Pb}$, and other metals including $\mathrm{Cd}$, from solution by biosorption and other accumulation mechanisms (Mowll and Gadd 1984; Radulovic et al. 2008). A. pullulans extensively synthesizes a mixture of extracellular pullulan-based polysaccharides and protein, which may enhance environmental survival and metal tolerance, being thought to play an important role in metal detoxification (Cheng et al. 2011; Suh et al. 1999). It was observed that the presence of EPS could influence adsorption of $\mathrm{Pb}^{2+}$ on the cell surfaces of A. pullulans and inhibit direct interactions with cellular components (Suh et al. 1999). However, the extracellular polysaccharide (pullulan) produced by A. pullulans $\mathrm{CH}-$ 1 apparently does not bind $\mathrm{Pb}$ or other metals, including $\mathrm{Cu}$, $\mathrm{Fe}, \mathrm{Zn}, \mathrm{Mn}, \mathrm{Cd}, \mathrm{Ni}$, and Cr (Radulovic et al. 2008).

Although the extracellular polysaccharide of A. pullulans and its significance for tolerance to toxic metals has been examined (Čertík et al. 2005; Mowll and Gadd 1984), information is limited and often contradictory, while the role of protein in fungal EPS has not been fully ascertained. Furthermore, there have been no reports focusing on the behaviour of A. pullulans when exposed to mercury or metalloids, e.g., arsenic and selenium. The aim of the present work was to study the effects of $\mathrm{Pb}^{2+}, \mathrm{Hg}^{2+}, \mathrm{As}^{3+}$, and $\mathrm{Se}^{4+}$ on the growth of A. pullulans and EPS production and composition, and to investigate complexation of EPS with these metals and metalloids using fluorescence spectroscopy. The results obtained shed further light on the potential interactions between metal(loid) elements and A. pullulans, and the significance of EPS in such interactions and metal tolerance.

\section{Material and methods}

\section{Microorganism and growth medium}

Aureobasidium pullulans de Bary (Arnaud) (IMI 45533) was sub-cultured from the Geomicrobiology Group collection, School of Life Sciences, University of Dundee. The strain was maintained on EPS production medium (EPM) consisting of the following $\left(\mathrm{g} \mathrm{L}^{-1}\right)$ : sucrose 50 ; peptone 0.6 ; yeast extract $0.4 ; \mathrm{K}_{2} \mathrm{HPO}_{4} 5.0 ; \mathrm{MgSO}_{4} \cdot 7 \mathrm{H}_{2} \mathrm{O} 0.4 ; \mathrm{NaCl} 1$, which were mixed and dissolved in Milli-Q water. The $\mathrm{pH}$ of the medium was adjusted to $\mathrm{pH} 6.0$ using $1 \mathrm{M} \mathrm{HCl}$ or $\mathrm{NaOH}$ and then autoclaved at $115^{\circ} \mathrm{C}$ for $15 \mathrm{~min}$ before use.

\section{Solution preparation}

Two metal elements $(\mathrm{Hg}$ and $\mathrm{Pb})$ and two metalloid elements (As and Se) were chosen. Mercury and lead stock solutions were prepared using mercuric chloride $\left(\mathrm{HgCl}_{2}\right)$ and lead nitrate $\left(\mathrm{Pb}\left(\mathrm{NO}_{3}\right)_{2}\right)$, respectively. Sodium arsenite $\left(\mathrm{NaAsO}_{2}\right)$ and sodium selenite $\left(\mathrm{Na}_{2} \mathrm{SeO}_{3}\right)$ were used to prepare the arsenic and selenium stock solutions. All solutions were sterilized by 
filtering through $0.45-\mu \mathrm{m}$ cellulose nitrate membrane filters (Minisart syringe filters, Sartorius, Göttingen, Germany) and stored at $4{ }^{\circ} \mathrm{C}$ prior to use.

\section{Effect of metals and metalloids on growth of A. pullulans}

All experiments were carried out using EPM medium. As exogenous stress factors, 0.01 and $0.1 \mathrm{mM} \mathrm{Hg}, 0.1$ and $1 \mathrm{mM} \mathrm{Pb}, 1$ and $10 \mathrm{mM} \mathrm{As}$, and 1 and $10 \mathrm{mM}$ Se were incorporated into the media. These stress factors were added at the beginning of the growth experiments when flasks were inoculated from an exponentially growing liquid starter culture of A. pullulans. The experimental flasks were inoculated to an initial $\mathrm{OD}_{600}$ of 0.3 from this starter culture and were incubated at $25^{\circ} \mathrm{C}$ for $96 \mathrm{~h}$ in a shaking incubator (120 rpm). Tolerance indices (TI) were used to compare optical density values in EPM medium with or without the stress factors. A TI value lower than 1 indicated growth inhibition; a TI value larger than 1 suggested growth stimulation (Sayer et al. 1995).

\section{Extraction and purification of EPS}

EPS was extracted by high-speed freezing centrifugation (Chu et al. 2015; Zhao et al. 2015). Briefly, cultures were centrifuged at $4{ }^{\circ} \mathrm{C}(2012 \mathrm{~g}, 20 \mathrm{~min})$ to obtain cell pellets and an EPS-containing supernatant. After that, the supernatant was purified by dialysis using a $3500 \mathrm{Da}$ membrane for $24 \mathrm{~h}$ at $4{ }^{\circ} \mathrm{C}$, and then the EPS precipitated with two volumes of ethanol (95\%). The ethanol was added slowly into the supernatant with constant stirring, stored at $4{ }^{\circ} \mathrm{C}$ overnight, and the precipitate collected by centrifugation at $4{ }^{\circ} \mathrm{C}(2012 g$, $20 \mathrm{~min}$ ). Cell pellets (after washing with MilliQ water) and EPS were collected and dried at $50{ }^{\circ} \mathrm{C}$ to constant weight. EPS yield was normalized as mg EPS per g cell dry weight.

\section{Analysis of biochemical components of EPS}

Polysaccharide content was measured using the phenolsulfuric acid method, using glucose as the standard (Nielsen 2010). Protein content was measured using the Bradford method, with bovine serum albumin as standard (Kruger 2009).

\section{Excitation-emission matrix fluorescence spectroscopy: fluorescence quenching titrations}

All excitation-emission matrix (EEM) spectra were obtained using a fluorescence spectrophotometer (F-7000, Hitachi, Japan) equipped with a 1.0-cm quartz cell and a thermostatic bath (Song et al. 2016b). EEM spectra were collected by scanning emission wavelengths from 200 to $500 \mathrm{~nm}$ in 2-nm increments by varying the excitation wavelengths from 200 to
$450 \mathrm{~nm}$ in $5-\mathrm{nm}$ increments. The width of the excitation/ emission slit was set to $5 \mathrm{~nm}$ and the scanning speed was set to $1200 \mathrm{~nm} / \mathrm{min}$. All EPS sample were diluted 10 times and titrated with incremental microliter additions of $10 \mathrm{mM}$ metal(loid) $(\mathrm{Hg}, \mathrm{Pb}, \mathrm{As}$, and $\mathrm{Se})$ solutions at $25^{\circ} \mathrm{C}$. After each addition, the EPS solution was fully mixed using a magnetic stirrer for $15 \mathrm{~min}$ and the fluorescence spectra recorded. The fluorometer's response to a Milli-Q water blank solution was subtracted from the fluorescence spectra recorded for EPS samples under the same conditions. All titration experiments were carried out in triplicate and the mean values calculated. EEM data were processed using Sigmaplot 10.0 software (Systat, USA).

\section{Results}

\section{Effect of metals and metalloids on growth of A. pullulans}

The optical density of cell suspensions at $600 \mathrm{~nm}\left(\mathrm{OD}_{600}\right)$ was used to assess growth in the presence of different metals and metalloids. Growth of A. pullulans at different concentrations of metals and metalloids after 96-h incubation is shown in Fig. 1. Cell growth was significantly inhibited by $\mathrm{Hg}$ and Se. As caused little inhibition of growth of cells, while low concentrations of $\mathrm{Pb}(0.1 \mathrm{mM})$ had no effect on growth. A higher $\mathrm{Pb}$ concentration $(1 \mathrm{mM})$ slightly increased the optical density which is thought to be a result of lead precipitation with growth medium components. Calculation of TI values confirmed these results. Mercury exhibited the highest

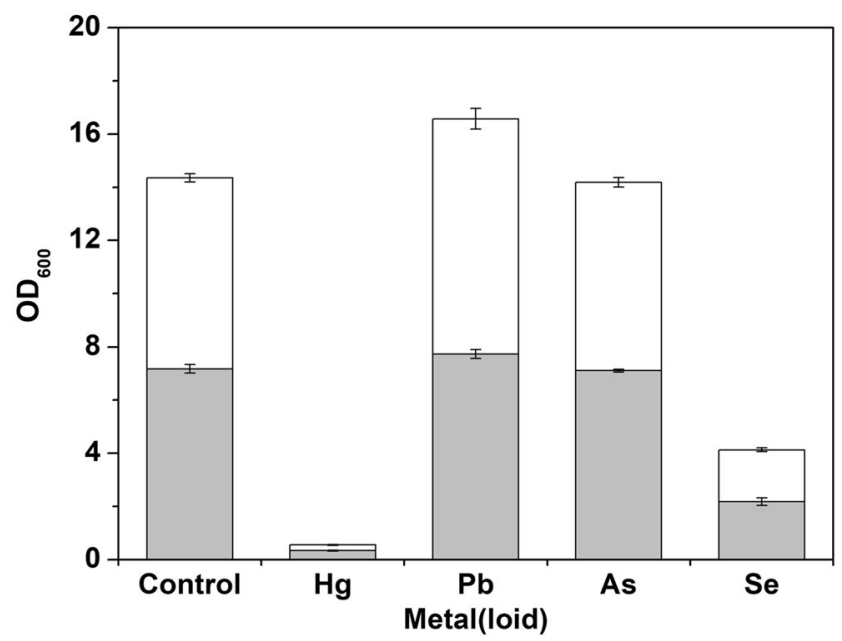

Fig. 1 Optical density (at $600 \mathrm{~nm}$ ) of A. pullulans cell suspensions after incubation for $96 \mathrm{~h}$ in the absence or presence of metal(loid)s at high ( $\square$ ) or low ( $\square$ ) concentrations (high concentrations of $\mathrm{Hg}, \mathrm{Pb}$, As, and Se were $0.1,1,10$, and $10 \mathrm{mM}$, respectively: low concentrations of $\mathrm{Hg}, \mathrm{Pb}$, As, and Se were $0.01,0.1,1$, and $1 \mathrm{mM}$, respectively). Bars are the standard deviation of average values 


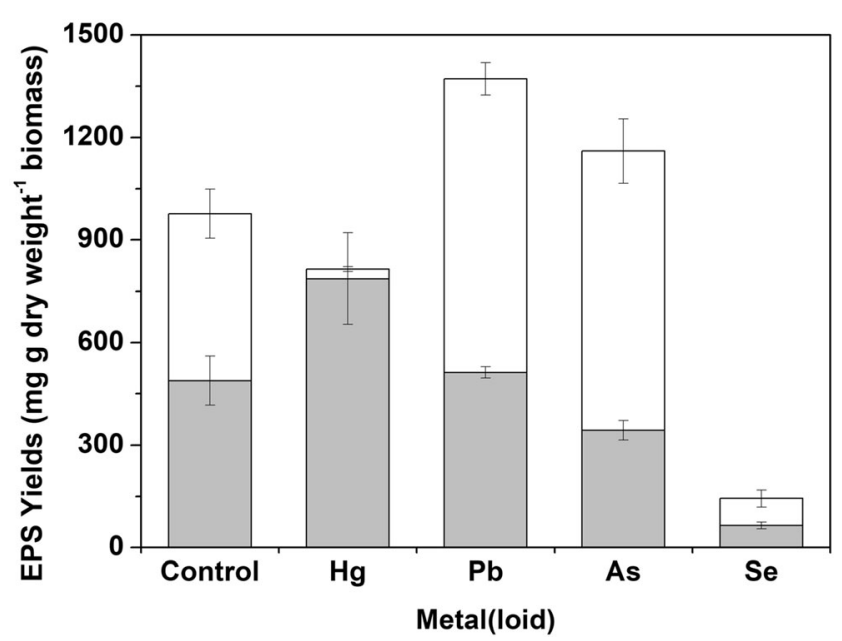

Fig. 2 EPS yields from A. pullulans incubated for $96 \mathrm{~h}$ in the absence or presence of metal(loid)s at high $(\square$ ) or low ( $\square$ ) concentrations (high concentrations of $\mathrm{Hg}, \mathrm{Pb}, \mathrm{As}$, and $\mathrm{Se}$ were $0.1,1,10$, and $10 \mathrm{mM}$, respectively: low concentrations of $\mathrm{Hg}, \mathrm{Pb}, \mathrm{As}$, and Se were $0.01,0.1,1$, and $1 \mathrm{mM}$, respectively). Bars are the standard deviation of average values

toxicity to A. pullulans at low ( $\mathrm{TI}=0.05)$ and high concentrations $(\mathrm{TI}=0.03)$. Selenium also significantly inhibited the growth of A. pullulans at low $(\mathrm{TI}=0.30)$ and high concentrations $(\mathrm{TI}=0.27)$. Lead slightly enhanced the growth of A. pullulans both at low $(\mathrm{TI}=1.07)$ and high concentrations ( $\mathrm{TI}=1.23)$. Arsenic slightly inhibited growth of $A$. pullulans at low $(\mathrm{TI}=0.99)$ and high concentrations $(\mathrm{TI}=0.99)$.

\section{Effect of metals and metalloids on the yield and composition of EPS from A. pullulans}

Figure 2 shows the EPS yields at different concentrations of metals and metalloid elements. A. pullulans in control EPM could produce EPS at $488.4 \mathrm{mg} \mathrm{g}^{-1}$ dry weight biomass. At

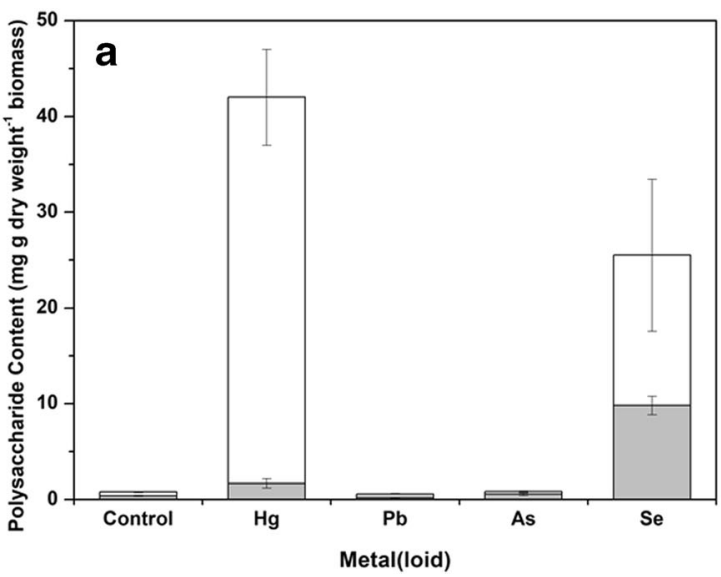

Fig. 3 Polysaccharide (a) and protein (b) content of the EPS from A. pullulans incubated for $96 \mathrm{~h}$ in the absence or presence of metal(loid)s at high ( $\square$ ) or low $(\square)$ concentrations (high concentrations of $\mathrm{Hg}, \mathrm{Pb}, \mathrm{As}$, and Se were $0.1,1,10$, and $10 \mathrm{mM}$, the low concentration of the tested elements, mercury produced the highest amount of EPS with a value of $787.4 \mathrm{mg} \mathrm{g}^{-1}$ dry weight biomass, followed by $\mathrm{Pb}$, As, and Se. Under mercury stress, the apparent high production of EPS but negligible cell growth might be attributable to the release of lipids and nucleic acids via cell lysis due to the toxicity of mercury particularly in the later stages of cell culture. At the high concentration of the tested elements, the $\mathrm{Pb}$ treatment showed the highest yield of EPS $\left(858.9 \mathrm{mg} \mathrm{g}^{-1}\right.$ dry weight biomass), followed by As ( $816.5 \mathrm{mg} \mathrm{g}^{-1}$ dry weight biomass).

The chemical composition of EPS is very heterogeneous and mainly composed of carbohydrates, proteins, lipids, and nucleic acids. Figure 3 shows the content of polysaccharide and protein in EPS from A. pullulans incubated with or without metals and metalloids. The content of protein $(4.62 \pm$ $0.50 \mathrm{mg}$ g dry weight ${ }^{-1}$ biomass) was much greater than that of polysaccharide $\left(0.26 \pm 0.09 \mathrm{mg}\right.$ g dry weight ${ }^{-1}$ biomass $)$ in the A. pullulans EPS incubated without metal(loids). It was also found that the polysaccharide content in the presence of $\mathrm{Pb}$ and $\mathrm{As}$ was similar to that of the control (Fig. 3a). The highest content of polysaccharide in the EPS occurred with mercury stress at the higher concentration, followed by the selenium treatment at both low and high concentrations. Regarding the protein content, the presence of selenium resulted in a higher protein content compared with the other tested elements (Fig. 3b). The $\mathrm{Pb}$ and As treatments at both low and high concentrations showed a slight increase in protein content compared with the control. However, negligible protein was found in the EPS with mercury. These results indicated that $\mathrm{Pb}$ and As did not significantly change the composition of the EPS. However, $\mathrm{Hg}$ and Se significantly changed the composition of the EPS compared with the control, which may reflect the toxicity of these elements towards A. pullulans.

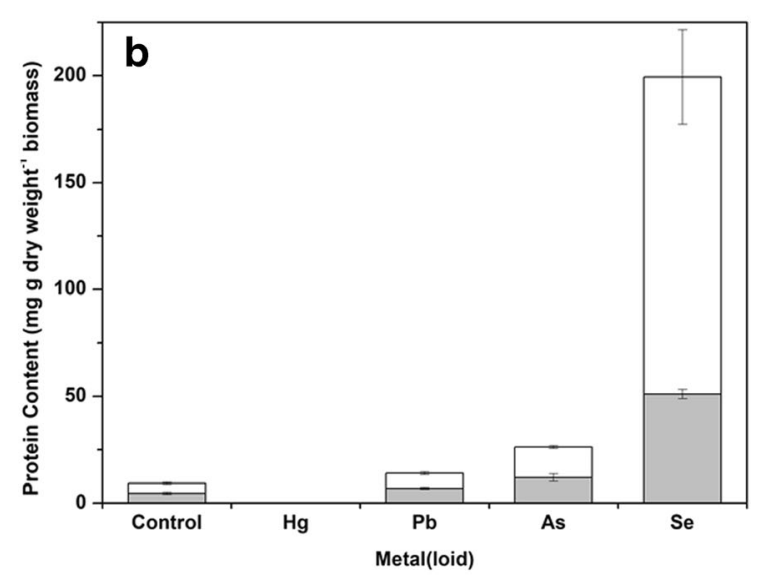

respectively: low concentrations of $\mathrm{Hg}, \mathrm{Pb}$, As, and Se were $0.01,0.1$, 1 , and $1 \mathrm{mM}$, respectively). Bars are the standard deviation of average values 
Fluorescence characteristics of EPS from A. pullulans

Two fluorescence peaks were observed in the EEM spectra of the EPS. Peak A (Ex/Em, 275-280/330-340) and peak B (Ex/ Em, 225/330-340) are attributable to tryptophan-like and aromatic protein-like fluorophores, respectively. The excitation /emission wavelength of the fluorescence peaks showed a slight blue/red shift, indicating that the presence of metals in the media had no influence on the type of fluorescent components of the excreted EPS (Table 1). The fluorescence intensity of EPS from A. pullulans grown in media amended with metals clearly increased, indicating that the presence of metals stimulated the production of extracellular tryptophan-like and aromatic protein-like substances. The higher metal concentrations stimulated a greater production of fluorescent substances.

\section{Fluorescence quenching}

Three-dimensional fluorescence spectra of EPS and the EPSmetal system are shown in Fig. 4. The fluorescence intensity of peaks A and B decreased significantly after addition of $\mathrm{Hg}$, $\mathrm{Pb}$, and As indicating that these three metal(loid)s have a strong interaction with the EPS and thus quench its fluorescence. The fluorescence intensity of both peaks showed a slight decrease after addition of Se, indicating that Se has little influence on EPS fluorescence.

The fluorescence quenching process can be interpreted as dynamic quenching, which is due to collisions between the fluorophore and quencher, or static quenching due to complexation between the fluorophore and the quencher. The Stern-Volmer Eq. (1) was used to judge whether the quenching processes observed here were dynamic or static:
$F_{0} / F=1+k_{\mathrm{q}} \tau_{0}[\mathrm{Q}]=1+K_{\mathrm{sV}}[\mathrm{Q}]$

where $F_{0}$ and $F$ represent the fluorescence intensity in the absence and presence of the quencher, respectively. $k_{\mathrm{q}}$ is the quenching rate constant; $K_{\mathrm{sv}}$ is the quenching constant; $\tau_{0}$ is the average lifetime of the fluorescence in the absence of the quencher, which is taken as $10^{-8} \mathrm{~s}$; and [Q] is the metal concentration.

Figure 4 shows that within the tested $\mathrm{Hg}, \mathrm{Pb}$, and As concentration ranges, the change of fluorescence intensity agreed well with the Stern-Volmer equation (Table 2). Furthermore, the quenching rate constant $\left(K_{\mathrm{q}}\right)$ values for $\mathrm{Hg}, \mathrm{Pb}$, and $\mathrm{As}$ to EPS were one order of magnitude larger than the maximum diffusion collision quenching rate constant $\left(2.0 \times 10^{10} / \mathrm{M} / \mathrm{s}\right)$ for a variety of quenchers with biopolymers, indicating that the fluorescence quenching process was mainly governed by static quenching by the formation of complexes.

\section{Binding constants and binding sites}

For ligand molecules that bind independently to a set of equivalent sites on a macromolecule, the equilibrium between free and bound molecules is given by the Hill Equation (2):

$\log \left[\left(F_{0}-F\right) / F\right]=\log K_{\mathrm{b}}+n \log [\mathrm{Q}]$

where $F_{0}$ and $F$ are the fluorescence intensities in the absence and presence of the quencher, respectively. $K_{\mathrm{b}}$ is the binding constant, $n$ is the number of binding sites, and [Q] is the metal concentration. The binding constants $\left(K_{\mathrm{b}}\right)$ reflect the interactive intensity between the EPS and the metal.

The binding constants $\left(\log K_{\mathrm{b}}\right)$ and the number of binding sites $(n)$ of the EPS-metal system are listed in Table 3. The

Table 1 Fluorescence position (Ex/Em, nm) and intensity (arbitrary units) of EPS from A. pullulans in the absence and presence of metal(loids). Intensities are average values from several determinations

\begin{tabular}{|c|c|c|c|c|c|}
\hline \multicolumn{2}{|l|}{ Stress factor } & \multicolumn{4}{|c|}{ Fluorescence peak and intensity } \\
\hline & & \multicolumn{2}{|l|}{ Peak A } & \multicolumn{2}{|l|}{ Peak B } \\
\hline Metal(loid) & Concentration (mM) & Ex/Em & Intensity & Ex/Em & Intensity \\
\hline Control & & $280 / 335$ & 586.4 & $225 / 330$ & 879.8 \\
\hline \multirow[t]{2}{*}{$\mathrm{Hg}^{2+}$} & 0.01 & $275 / 335$ & 1387 & $225 / 335$ & 1966 \\
\hline & 0.1 & $280 / 335$ & 1485 & $225 / 335$ & 2139 \\
\hline \multirow[t]{2}{*}{$\mathrm{Pb}^{2+}$} & 0.1 & $280 / 330$ & 873.6 & $225 / 325$ & 1231 \\
\hline & 1 & $280 / 340$ & 1025 & $225 / 330$ & 1212 \\
\hline \multirow[t]{2}{*}{$\mathrm{As}^{3+}$} & 1 & $280 / 335$ & 833 & $225 / 330$ & 1283 \\
\hline & 10 & $280 / 340$ & 1998 & $225 / 340$ & 2232 \\
\hline \multirow[t]{2}{*}{$\mathrm{Se}^{4+}$} & 1 & $280 / 335$ & 1141 & $225 / 335$ & 1906 \\
\hline & 10 & $280 / 330$ & 1585 & $225 / 330$ & 2105 \\
\hline
\end{tabular}


Fig. 4 Typical three-dimensional fluorescence EEM spectra (Ex and $\mathrm{Em}, \mathrm{nm}$ ) of EPS at $25^{\circ} \mathrm{C}$ in the absence and presence of different metal(loid)s. a EPS; b $\mathrm{EPS}+\mathrm{Hg} ; \mathbf{c} \mathrm{EPS}+\mathrm{Pb} ; \mathbf{d}$ EPS + As; e EPS + Se). The experimental concentration ranges of detected metal(loid)s for EEM were $0-0.15 \mathrm{mM}(\mathrm{Hg}) ; 0$ $0.11 \mathrm{mM}(\mathrm{Pb}) ; 0-0.15 \mathrm{mM}(\mathrm{As})$; and $0-0.1 \mathrm{mM}(\mathrm{Se})$. Typical spectra are shown from several determinations
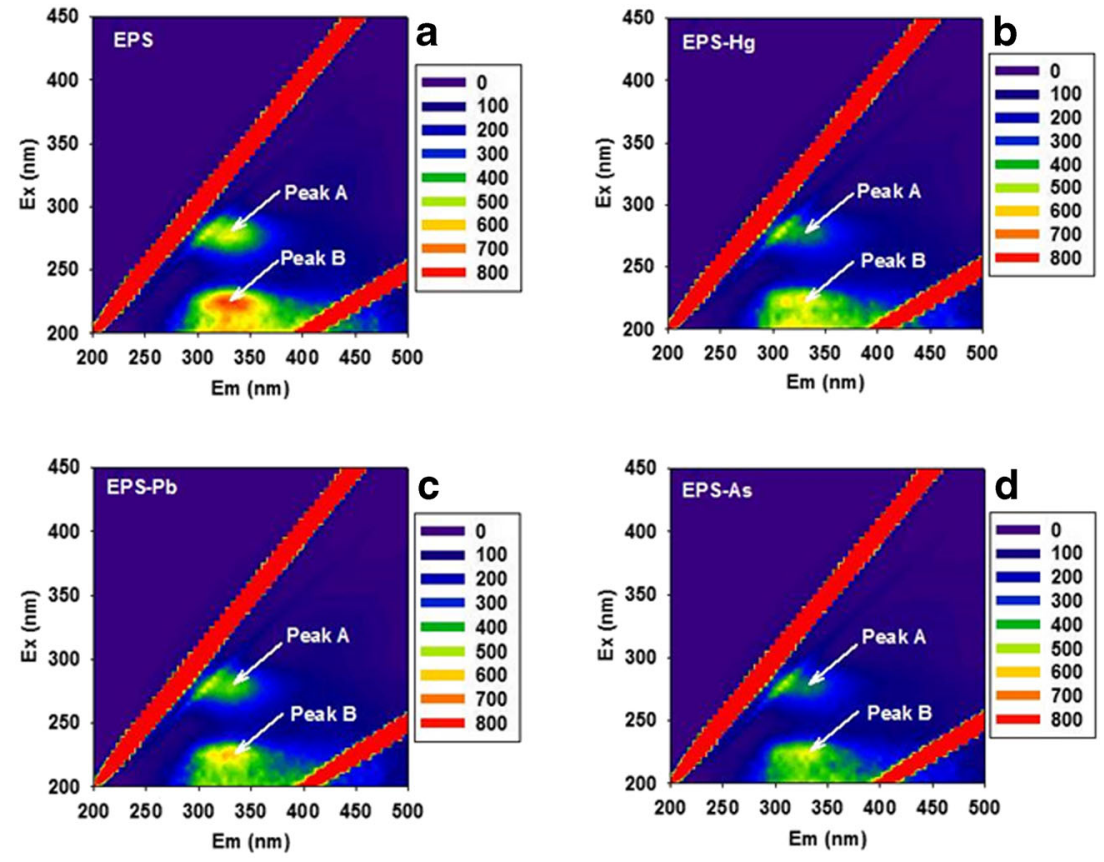

maximum value of $\log K_{\mathrm{b}}$ was obtained from the EPS-Hg(II) system at peak $\mathrm{A}$, indicating that the tryptophan-like substances had a stronger ability to bind $\mathrm{Hg}(\mathrm{II})$. The $\log K_{\mathrm{b}}$ and $n$ of tryptophan-like substances (peak A) for the metals and metalloids both showed the same order of $\mathrm{Hg}>\mathrm{Pb}>\mathrm{As}$.
Mercury had the higher $\log K_{\mathrm{b}}$ and $n$ for aromatic proteinlike substances (peak B) with metals, followed by As and $\mathrm{Pb}$. For the same metal or metalloid, the $\log K_{\mathrm{b}}$ and $n$ of tryptophan-like substances (peak A) were higher than those for aromatic protein-like substances (peak B), indicating that
Table 2 Stern-Volmer fluorescence quenching constants, $K_{\mathrm{sv}}$, and quenching rate constant, $K_{\mathrm{q}}$, of EPS from A. pullulans in the presence of different metals ( $\mathrm{Hg}$ concentration range $0-0.15 \mathrm{mM}$; $\mathrm{Pb}$ concentration range $0-0.11 \mathrm{mM}$; As concentration range $0-0.15 \mathrm{mM}$; Se concentration range $0-0.1 \mathrm{mM} ; R^{2}$, determination coefficients)

\begin{tabular}{llllr}
\hline Quencher & & $\begin{array}{l}\text { Quenching } \\
\text { constants } K_{\text {sv }} \\
\left(\times 10^{3} / \mathrm{M}\right)\end{array}$ & $\begin{array}{l}\text { Quenching rate } \\
\text { constants } K_{\mathrm{q}} \\
\left(\times 10^{11} / \mathrm{M} / \mathrm{s}\right)\end{array}$ \\
\hline $\mathrm{Hg}$ & Peak A & 2.61 & 2.61 & 0.8813 \\
& Peak B & 3.14 & 3.14 & 0.8650 \\
$\mathrm{~Pb}$ & Peak A & 2.30 & 2.30 & 0.8329 \\
& Peak B & 2.18 & 2.18 & 0.7548 \\
$\mathrm{As}$ & Peak A & 2.69 & 3.12 & 0.9368 \\
& Peak B & 3.12 & 0.67 & 0.9586 \\
$\mathrm{Se}$ & Peak A & 0.67 & 0.87 & 0.3196 \\
& Peak B & 0.87 & 0.5108 \\
\hline
\end{tabular}


Table 3 Binding constants ( $\log K_{\mathrm{b}}$ ) and number of binding sites $(n)$ for A. pullulans EPS complexation with different metals (Hg concentration range $0-0.15 \mathrm{mM} ; \mathrm{Pb}$ concentration range $0-0.11 \mathrm{mM}$; As concentration range $0-0.15 \mathrm{mM}$; Se concentration range $0-0.1 \mathrm{mM} ; R^{2}$, determination coefficients)

\begin{tabular}{llccc}
\hline Metal(loid) & Binding constant $\left(\log K_{\mathrm{b}}\right)$ & $\begin{array}{l}\text { Binding } \\
\text { sites }(n)\end{array}$ & $R^{2}$ \\
\hline $\mathrm{Hg}(\mathrm{II})$ & Peak A & 6.76 & 1.89 & 0.9065 \\
& Peak B & 6.08 & 1.69 & 0.8887 \\
$\mathrm{~Pb}(\mathrm{II})$ & Peak A & 4.00 & 1.17 & 0.7984 \\
& Peak B & 1.08 & 0.42 & 0.7236 \\
$\mathrm{As}(\mathrm{III})$ & Peak A & 2.61 & 0.79 & 0.9369 \\
& Peak B & 2.18 & 0.66 & 0.9557 \\
\hline
\end{tabular}

the tryptophan-like substances had a stronger binding ability for $\mathrm{Hg}, \mathrm{As}$, and $\mathrm{Pb}$ than aromatic protein-like substances. However, EPS showed no binding ability for Se. These results implied that $\mathrm{Hg}, \mathrm{Pb}$, and $\mathrm{As}$ could interact with fluorescent components, resulting in the formation of a stable nonfluorescent complex between the EPS and the metal/ metalloid species.

\section{Discussion}

Toxic metals can exert a variety of effects on the morphology and physiology of fungi, including A. pullulans (Gadd and Griffiths 1980; Gadd and Mowll 1985; Gadd et al. 1986; Newby and Gadd 1987; Ramsay et al. 1999; Fomina et al. 2000). In this study, mercury and selenium had a negative effect on the growth of A. pullulans, but lead and arsenic had no significant influence on the growth of $A$. pullulans at the concentrations tested. At higher concentrations of lead, it even appeared to stimulate growth of this fungus as measured by $\mathrm{OD}_{600}$, although this was probably a result of lead precipitation as sulfate/chloride which are present as medium components (Gadd and Griffiths 1978; Gadd 1992). The other results indicated that the effects of the test metal(loid)s on the growth of $A$. pullulans depended on the concentration and the element concerned. Growth inhibition by selenium in liquid EPM media was more pronounced than results obtained from growth on solid agar media (Liang et al. 2019), probably reflective of binding interactions in the solid medium that can result in alleviation of toxicity (Gadd and Griffiths 1978; Gadd 1992). A. pullulans can exhibit a high biosorption capacity for lead (Suh et al. 2001). This is unsurprising since $\mathrm{Pb}$ has a very strong binding affinity for biomass components and, as mentioned, is also likely to precipitate out of solution as e.g. phosphate, chloride, or sulfate, which will also associate with biomass. Because of such effects, $\mathrm{Pb}$ bioavailability is frequently low and this can underlie such tolerance to apparently high $\mathrm{Pb}$ concentrations. Furthermore, the melanized walls of chlamydospores and other cell forms of A. pullulans show high metal binding and act as an impermeable barrier to toxic metals (Gadd 1984; Gadd et al. 1984; Mowll and Gadd 1984). Such properties and $\mathrm{Pb}$ chemistry explain why A. pullulans is often the dominant organism on phylloplanes contaminated with industrial or vehicular $\mathrm{Pb}$ emissions (Bewley and Campbell 1980; Mowll and Gadd 1985). Because of the ease of high biomass generation and metal tolerance, A. pullulans has been suggested to be a useful organism for certain metal bioremediation applications (Nakkeeran et al. 2018).

Exopolysaccharides and proteins are often reported to have important roles in complexation of metals in solution (Comte et al. 2008; Guibaud et al. 2009; Huang et al. 2011). In this study, the extracellular protein content was higher than that of the exopolysaccharides in the EPS produced in the presence of $\mathrm{Pb}, \mathrm{As}$, and $\mathrm{Se}$. This result is different to some other studies on the composition of EPS from other microorganisms, such as P. chrysosporium, which showed a higher content of polysaccharide than protein in the EPS (Li et al. 2017). However, another study found that the EPS from an algal biofilm had a higher content of protein than polysaccharide (Ma et al. 2018). It has also been observed that the ratio of protein to polysaccharide in the EPS from Acidithiobacillus ferrooxidans was significantly influenced by the $\mathrm{pH}$ of media (Song et al. 2016a). The yeast Rhodotorula mucilaginosa was also found to secrete more polysaccharides when exposed to $\mathrm{Pb}^{2+}$ at high concentrations (1000-2500 mg/L) (Li et al. 2019) while a higher protein content in EPS was detected in sludge exposed to lead and copper (Jang et al. 2001; Wang et al. 2015). Arsenic stress was also found to increase the protein and carbohydrate content in EPS from bacteria isolated from industrial wastewater (Saba et al. 2019). Changes in the composition of EPS under $\mathrm{Hg}$ and Se stress may therefore contribute to the tolerance of $A$. pullulans to toxic metals by affecting metal bioavailability: metals have high binding affinities to amino acids, peptides, and proteins (Mejáre and Bülow 2001). Furthermore, many toxic metals can cause lysis of cell membranes and leakage of intracellular content (Gadd et al. 1986) which would also influence the yield and composition of EPS as measured in this study. This is particularly likely to have occurred with $\mathrm{Hg}$.

Fluorescence spectroscopy is a powerful technique for identification of the components of EPS and their interactions with metals. In this study, $\mathrm{Hg}, \mathrm{Pb}$, and As showed a strong interaction with tryptophan-like and aromatic protein-like fluorophores, while Se had no obvious interaction with these components. Some other studies have described the interaction of EPS with mercury, lead, and arsenic using fluorescence spectroscopy and have obtained similar results. The fluorescence of EPS produced by activated sludge (Song et al. 2012), pure bacterial cultures (Baldi et al. 2017), and an algal biofilm 
(Ma et al. 2018) was all quenched by Pb. The fluorescence of EPS from an algal biofilm and pure bacterial cultures was also significantly quenched by $\mathrm{Hg}$ (Song et al. 2012; Zhang et al. 2010) and As (Lin et al. 2018). It is possible that siderophore production might contribute to fluorescence, but this was not investigated in this study: A. pullulans is capable of siderophore excretion (Wang et al. 2009). FTIR analysis of bacterial EPS also revealed the involvement of phosphate, carboxyl and hydroxyl, or amine functional groups from polysaccharides and proteins in the interactions with lead (Song et al. 2012) and arsenic (Saba et al. 2019). Some previous studies also demonstrated the involvement of protein in the EPS of a cyanobacterial biofilm in complexation of mercury and arsenic (Lin et al. 2018; Ma et al. 2018; Zhang et al. 2015).

The quenching constants of EPS for metals and metalloids were in the range $0.67-3.14$ in this study. These values were different from those recorded for an algal biofilm, activated sludge, and certain bacterial strains (Lin et al. 2018; Ma et al. 2018; Song et al. 2016b; Zhang et al. 2010). The quenching rate constant value for $\mathrm{Pb}$ and EPS from the algal biofilm was between 3.61 and 8.54 (Ma et al. 2018), which is greater than that found in this study. It has been found that the quenching process of tryptophan-like substances by As belonged to dynamic quenching, but aromatic protein-like substances showed complexation with As (Lin et al. 2018). Furthermore, the $K_{\mathrm{q}}$ values for Se interactions with EPS in this study were one order of magnitude smaller than $2.0 \times$ $10^{10} / \mathrm{M} / \mathrm{s}$, indicating that the fluorescence quenching process was dominated by dynamic quenching due to intermolecular collisions. However, the quenching process between chemically synthesized SeNPs and EPS from the selenite-reducing bacterium Citrobacter freundii $\mathrm{Y} 9$ combined both static and dynamic quenching (Wang et al. 2018). These results imply that both the microbial species and elemental form might affect the interactions with EPS. The binding constants $\left(\log K_{\mathrm{b}}\right)$ for metals and metalloids to the EPS from A. pullulans were in the range 1.08-6.76 that are consistent with previous studies. It was found that the binding constant value, $\log K_{\mathrm{b}}$, was 3.45 4.52 for $\mathrm{Pb}$ to EPS from an algal biofilm (Ma et al. 2018), and 6.15-7.77 for that from activated sludge (Song et al. 2012). The binding constant value, $\log K_{\mathrm{b}}$, was $2.22-3.82$ for As to EPS from an algal biofilm (Lin et al. 2018). The maximal value of the binding constant was 3.14 for $\mathrm{Hg}$ to EPS from A. ferrooxidans at $\mathrm{pH} \mathrm{8}$, and 7.06-7.09 for cyanobacterial EPS from a Chroococcus sp. (Song et al. 2016a, b). From the above, it can be concluded that the complexation and binding ability of microbial EPS to metal/metalloid elements is strongly dependent on the microbial species and the particular element involved. Overall, it can also be concluded that changes in the composition of EPS induced by potentially toxic metal(loid)s, which affect metal bioavailability, can contribute to metal tolerance and survival.
Author contributions WS and GMG conceived and designed the research, interpreted the data, finalized conclusions, and wrote the manuscript. WS conducted experimental work. YY and FL provided advice and assistance with analytical and chemical analyses and data analysis. $\mathrm{XL}$ provided assistance with organism growth and manipulation and data analysis. All authors read and approved the manuscript.

Funding information This work was supported by the National Natural Science Foundation of China (grant number 41673127) and grants from the Youth Innovation Promotion Association of the Chinese Academy of Sciences (grant number 2017478). Financial support of the Geomicrobiology Group is received from the Natural Environment Research Council (NE/M010910/1 (TeaSe); NE/M011275/1 ( $\left.\mathrm{COG}^{3}\right)$ ), which is gratefully acknowledged.

\section{Compliance with ethical standards}

Conflict of interest The authors declare that they have no competing interests.

Ethical statement This article does not contain any studies with human participants or animals performed by any of the authors.

Open Access This article is licensed under a Creative Commons Attribution 4.0 International License, which permits use, sharing, adaptation, distribution and reproduction in any medium or format, as long as you give appropriate credit to the original author(s) and the source, provide a link to the Creative Commons licence, and indicate if changes were made. The images or other third party material in this article are included in the article's Creative Commons licence, unless indicated otherwise in a credit line to the material. If material is not included in the article's Creative Commons licence and your intended use is not permitted by statutory regulation or exceeds the permitted use, you will need to obtain permission directly from the copyright holder. To view a copy of this licence, visit http://creativecommons.org/licenses/by/4.0/.

\section{References}

Baldi F, Gallo M, Daniele S, Battistel D, Faleri C, Kodre A, Arčon I (2017) An extracellular polymeric substance quickly chelates mercury (II) with N-heterocyclic groups. Chemosphere 176:296-304

Bewley RJF, Campbell R (1980) Influence of zinc, lead and cadmium pollutants on the microflora of hawthorn leaves. Microbial Ecol 6: 227-240

Bhadra B, Rao RS, Singh PK, Sarkar PK, Shivaji S (2008) Yeasts and yeast-like fungi associated with tree bark: diversity and identification of yeasts producing extracellular endoxylanases. Curr Microbiol 56:489-494

Cao F, Bourven I, Guibaud G, Rene ER, Lens PNL, Pechaud Y, van Hullebusch ED (2018) Alteration of the characteristics of extracellular polymeric substances (EPS) extracted from the fungus Phanerochaete chrysosporium when exposed to sub-toxic concentrations of nickel (II). Int Biodeterior Biodegrad 129:179-188

Čertík M, Breierová E, Juršíková P (2005) Effect of cadmium on lipid composition of Aureobasidium pullulans grown with added extracellular polysaccharides. Int Biodeterior Biodegrad 55:195-202

Cheng K-C, Demirci A, Catchmark JM (2011) Pullulan: biosynthesis, production, and applications. Appl Microbiol Biotechnol 92:29-44

Chu H, Yu H, Tan X, Zhang Y, Zhou X, Yang L, Li D (2015) Extraction procedure optimization and the characteristics of dissolved extracellular organic matter (dEOM) and bound extracellular organic matter 
(bEOM) from Chlorella pyrenoidosa. Colloids Surf B: Biointerfaces 125:238-246

Comte S, Guibaud G, Baudu M (2008) Biosorption properties of extracellular polymeric substances (EPS) towards $\mathrm{Cd}, \mathrm{Cu}$ and $\mathrm{Pb}$ for different $\mathrm{pH}$ values. J Hazard Mater 151:185-193

De Philippis R, Colica G, Micheletti E (2011) Exopolysaccharideproducing cyanobacteria in heavy metal removal from water: molecular basis and practical applicability of the biosorption process. Appl Microbiol Biotechnol 92:697-708

Deshpande MS, Rale VB, Lynch JM (1992) Aureobasidium pullulans in applied microbiology: a status report. Enzym Microb Technol 14: 514-527

Fomina M, Gadd GM (2014) Biosorption: current perspectives on concept, definition and application. Bioresour Technol 160:3-14

Fomina M, Ritz K, Gadd GM (2000) Negative fungal chemotropism to toxic metals. FEMS Microbiol Lett 193:207-211

Fomina M, Hillier S, Charnock JM, Melville K, Alexander IJ, Gadd GM (2005) Role of oxalic acid over-excretion in toxic metal mineral transformations by Beauveria caledonica. Appl Environ Microbiol $71: 371-381$

Gadd GM (1980) Melanin production and differentiation in batch cultures of the polymorphic fungus Aureobasidium pullulans. FEMS Microbiol Lett 9:237-240

Gadd GM (1984) Effect of copper on Aureobasidium pullulans in solid medium: adaptation not necessary for tolerant behaviour. Trans Brit Mycol Soc 82:546-549

Gadd GM (1992)Metals and microorganisms: a problem of definition. FEMS Microbiol Lett 100:197-204

Gadd GM (2000) Bioremedial potential of microbial mechanisms of metal mobilization and immobilization. Curr Opin Biotechnol 11:271279

Gadd GM (2004) Microbial influence on metal mobility and application for bioremediation. Geoderma 122:109-119

Gadd GM (2010) Metals, minerals and microbes: geomicrobiology and bioremediation. Microbiology 156:609-643

Gadd GM, Griffiths AJ (1978) Microorganisms and heavy metal toxicity. Microbial Ecol 4:303-317

Gadd GM, Griffiths AJ (1980) Effect of copper on morphology of Aureobasidium pullulans. Trans Brit Mycol Soc 74:387-392

Gadd GM, Mowll JL (1985) Copper uptake by yeast-like cells, hyphae, and chlamydospores of Aureobasidium pullulans. Exp Mycol 9: 230-240

Gadd GM, Stewart A, White C, Mowll JL (1984) Copper uptake by whole cells and protoplasts of a wild-type and copper- resistant strain of Saccharomyces cerevisiae. FEMS Microbiol Lett 24:231234

Gadd GM, Mowll JL, White C, Newby PJ (1986) Methods for assessment of heavy metal toxicity towards fungi and yeasts. Toxic Assess $1: 169-185$

Guibaud G, van Hullebusch E, Bordas F, d'Abzac P, Joussein E (2009) Sorption of $\mathrm{Cd}(\mathrm{II})$ and $\mathrm{Pb}$ (II) by exopolymeric substances (EPS) extracted from activated sludges and pure bacterial strains: modeling of the metal/ligand ratio effect and role of the mineral fraction. Bioresour Technol 100:2959-2968

Gupta P, Diwan B (2017) Bacterial exopolysaccharide mediated heavy metal removal: a review on biosynthesis, mechanism and remediation strategies. Biotechnol Rep 13:58-71

Hou W, Ma Z, Sun L, Han M, Lu J, Li Z, Mohamad OA, Wei G (2013) Extracellular polymeric substances from copper-tolerant Sinorhizobium meliloti immobilize $\mathrm{Cu}^{2+}$. J Hazard Mater 261: 614-620

Huang JH, Elzinga EJ, Brechbuehl Y, Voegelin A, Kretzschmar R (2011) Impacts of Shewanella putrefaciens strain $\mathrm{CN}-32$ cells and extracellular polymeric substances on the sorption of $\mathrm{As}(\mathrm{V})$ and $\mathrm{As}(\mathrm{III})$ on Fe(III)-(hydr)oxides. Environ Sci Technol 45:2804-2810
Jang A, Kim SM, Kim SY, Lee SG, Kim IS (2001) Effect of heavy metals $(\mathrm{Cu}, \mathrm{Pb}$, and $\mathrm{Ni})$ on the compositions of EPS in biofilms. Water Sci Technol 43:41-48

Kruger NJ (2009) The Bradford method for protein quantitation. In: Walker JM (ed) The protein protocols handbook. Humana Press, Totowa, NJ, pp 17-24

Li N, Zhang X, Wang D, Cheng Y, Wu L, Fu L (2017) Contribution characteristics of the in situ extracellular polymeric substances (EPS) in Phanerochaete chrysosporium to $\mathrm{Pb}$ immobilization. Bioprocess Biosyst Eng 40:1447-1452

Li J, Jiang Z, Chen S, Wang T, Jiang L, Wang M, Wang S, Li Z (2019) Biochemical changes of polysaccharides and proteins within EPS under $\mathrm{Pb}$ (II) stress in Rhodotorula mucilaginosa. Ecotoxicol Environ Safety 174:484-490

Liang X, Perez MAM-J, Nwoko KC, Egbers P, Feldmann J, Csetenyi L, Gadd GM (2019) Fungal formation of selenium and tellurium nanoparticles. Appl Microbiol Biotechnol 103:7241-7259

Lin H, Wang C, Zhao H, Chen G, Chen X (2018) Interaction between copper and extracellular nucleic acids in the EPS of unsaturated Pseudomonas putida CZ1 biofilm. Environ Sci Pollut Res 25: 4172-4180

Liu H, Gu T, Asif M, Zhang G, Liu H (2017) The corrosion behavior and mechanism of carbon steel induced by extracellular polymeric substances of iron-oxidizing bacteria. Corros Sci 114:102-111

Ma Y, Song W, Zhao C (2018) The complexation of extracellular polymeric substances from alga-bacteria biofilm with heavy metal contained in lead-zinc mine tailings. Res Environ Sci 31:12961302 (in Chinese)

Mejáre M, Bülow L (2001) Metal-binding proteins and peptides in bioremediation and phytoremediation of heavy metals. Trends Biotechnol 19:67-73

Mowll JL, Gadd GM (1984) Cadmium uptake by Aureobasidium pullulans. J Gen Microbiol 130:279-284

Mowll JL, Gadd GM (1985) The effect of vehicular lead pollution on phylloplane mycoflora. Trans Brit Mycol Soc 84:685-689

Naik MM, Pandey A, Dubey SK (2012) Biological characterization of lead-enhanced exopolysaccharide produced by a lead resistant Enterobacter cloacae strain P2B. Biodegrad 23:775-783

Nakkeeran E, Rathna R, Viveka R (2018) Mechanism and action of Aureobasidium pullulans on biosorption of metals. In: Varjani SJ, Gnansounou E, Gurunathan B, Pant D, Zakaria ZA (eds) Waste bioremediation. Springer Singapore, Singapore, pp 215-231

Newby PJ, Gadd GM (1987) Synnema induction in Penicillium funiculosum by tributyltin compounds. Trans Brit Mycol Soc 89: 381-384

Nielsen SS (2010) Phenol-sulfuric acid method for total carbohydrates. In: Nielsen SS (ed) Food analysis laboratory manual. Springer US, Boston, MA, pp 47-53

Prabhakaran P, Ashraf MA, Aqma WS (2016) Microbial stress response to heavy metals in the environment. RSC Adv 6:862-877

Prasongsuk S, Lotrakul P, Ali I, Bankeeree W, Punnapayak H (2018) The current status of Aureobasidium pullulans in biotechnology. Folia Microbiol 63:129-140

Radulovic MD, Cvetkovic OG, Nikolic SD, Dordevic DS, Jakovljevic DM, Vrvic MM (2008) Simultaneous production of pullulan and biosorption of metals by Aureobasidium pullulans strain $\mathrm{CH}-1$ on peat hydrolysate. Bioresour Technol 99:673-677

Ramsay LM, Sayer JA, Gadd GM (1999) Stress responses of fungal colonies towards metals. In: Gow NAR, Robson GD, Gadd GM (eds) The fungal colony. Cambridge University Press, Cambridge, pp 178-200

Ravella SR, Quiñones TS, Retter A, Heiermann M, Amon T, Hobbs PJ (2010) Extracellular polysaccharide (EPS) production by a novel strain of yeast-like fungus Aureobasidium pullulans. Carbohyd Polymers 82:728-732 
Rhee YJ, Hillier S, Pendlowski H, Gadd GM (2014) Pyromorphite formation in a fungal biofilm community growing on lead metal. Environ Microbiol 16:1441-1451

Saba RY, Ahmed M, Sabri AN (2019) Potential role of bacterial extracellular polymeric substances as biosorbent material for arsenic bioremediation. Bioremediat J 23:72-81

Sayer JA, Raggett S, Gadd GM (1995) Solubilization of insoluble metal compounds by soil fungi: development of a screening method for solubilizing ability and metal tolerance. Mycol Res 99:987-993

Sheng GP, Xu J, Luo HW, Li WW, Li WH, Yu HQ, Xie Z, Wei SQ, Hu FC (2013) Thermodynamic analysis on the binding of heavy metals onto extracellular polymeric substances (EPS) of activated sludge. Water Res 47:607-614

Song WJ, Pan X, Zhang D (2012) Lead complexation of soluble and bound extracellular polymeric substances from activated sludge: characterized with fluorescence spectroscopy and FTIR spectroscopy. Biotechnol Biotechnol Equip 26:3371-3377

Song W, Deng C, Pan X, Zhang D, Al-Misned FA, Mortuza MG, Gadd GM (2016a) Effects of $\mathrm{pH}$ shock on $\mathrm{Hg}$ (II) complexation by exopolymers from Acidithiobacillus ferrooxidans. Geomicrobiol J $33: 325-331$

Song W, Zhao C, Zhang D, Mu S, Pan X (2016b) Different resistance to UV-B radiation of extracellular polymeric substances of two cyanobacteria from contrasting habitats. Front Microbiol 7:e1208

Suh JH, Yun JW, Kim DS (1999) Effect of extracellular polymeric substances (EPS) on $\mathrm{Pb}^{2+}$ accumulation by Aureobasidium pullulans. Bioprocess Eng 21:1-4

Suh JH, Kim DS, Song SK (2001) Inhibition effect of initial $\mathrm{Pb}^{2+}$ concentration on $\mathrm{Pb}^{2+}$ accumulation by Saccharomyces cerevisiae and Aureobasidium pullulans. Bioresour Technol 79:99-102
Wang WL, Chi ZM, Chi Z, , Li J, Wang XH (2009). Siderophore production by the marine-derived Aureobasidium pullulans and its antimicrobial activity. Bioresour Technol 100: 2639-2641

Wang Y, Qin J, Zhou S, Lin X, Ye L, Song C, Yan Y (2015) Identification of the function of extracellular polymeric substances (EPS) in denitrifying phosphorus removal sludge in the presence of copper ion. Water Res 73:252-264

Wang X, Zhang D, Qian H, Liang Y, Pan X, Gadd GM (2018) Interactions between biogenic selenium nanoparticles and goethite colloids and consequence for remediation of elemental mercury contaminated groundwater. Sci Total Environ 613-614:672-678

Yin K, Wang Q, Lv M, Chen L (2019) Microorganism remediation strategies towards heavy metals. Chem Eng J 360:553-563

Yue ZB, Li Q, Li CC, Chen TH, Wang J (2015) Component analysis and heavy metal adsorption ability of extracellular polymeric substances (EPS) from sulfate reducing bacteria. Bioresour Technol 194:399 402

Zhang D, Pan X, Mostofa KMG, Chen X, Mu G, Wu F, Liu J, Song W, Yang J, Liu Y, Fu Q (2010) Complexation between $\mathrm{Hg}(\mathrm{II})$ and biofilm extracellular polymeric substances: an application of fluorescence spectroscopy. J Hazard Mater 175:359-365

Zhang Y, Wang F, Zhu X, Zeng J, Zhao Q, Jiang X (2015) Extracellular polymeric substances govern the development of biofilm and mass transfer of polycyclic aromatic hydrocarbons for improved biodegradation. Bioresour Technol 193:274-280

Zhao W, Yang S, Huang Q, Cai P (2015) Bacterial cell surface properties: role of loosely bound extracellular polymeric substances (LB-EPS). Colloids Surf B 128:600-607

Publisher's note Springer Nature remains neutral with regard to jurisdictional claims in published maps and institutional affiliations. 